\title{
MJFAS MALAYSIAN JUURNAL OF

\section{Evaluation of nutritive values and consumer acceptance of sweet corn (Zea mays) juice as a recovery beverage for exercising people}

\author{
Normah Jusoh a, ${ }^{\text {, }}$ Azimah Ahmad ${ }^{\mathrm{a}, \mathrm{b}}$, Ruaibah Yazani Tengah ${ }^{\mathrm{a}}$ \\ a Fakulti Sains Sukan dan Kejurulatihan, Universiti Pendidikan Sultan Idris, Tanjung Malim, Malaysia \\ - Fakulti Perubatan dan Kesihatan Pertahanan, Universiti Pertahanan Nasional Malaysia, Kuala Lumpur, Malaysia \\ * Corresponding author: normah@fsskj.upsi.edu.my
}

\section{Article history}

Received 5 August 2018

Revised 9 Disember 2018

Accepted 26 February 2019

Published Online 25 August 2019

\begin{abstract}
Carbohydrate-protein (CP) drinks have been shown to exert better effect in promoting faster muscle recovery and rehydration in exercising individuals. However, not all active people, particularly Asians can consume milk-based CP drinks that would trigger symptoms of lactose intolerance and discomfort. Thus, this study aimed to assess the feasibility of sweet corn (Zea mays) beverage as an alternative recovery drink for active people due to its high content of carbohydrate and protein as well as lactosefree. The first phase of the study was the formulation of sweet corn juice that match the specific criteria for an effective recovery drink. Next, the study on the acceptance assessment of the new formulated sweet corn juice was conducted. The results show that the product contains high carbohydrate and protein contents which met the criteria for recovery beverage for active people. Besides, the results of sensory and hedonic evaluation demonstrate that the product was well-liked and accepted by majority of the consumers. To conclude, sweet corn juice which is lactose-free may offer extra benefits in such a way that it will provide alternative recovery drink that can be consumed by lactose intolerant active people.
\end{abstract}

Keywords: Sweet corn, beverage, nutrient composition, exercise

\section{INTRODUCTION}

It is common to for active individuals to experience hypohydration and muscle soreness particularly after vigorous exercises. Therefore, effective recovery is important to prepare the body for the next session of exercise. Recovery consists of muscle glycogen restoration, fluid loss replacement, and muscle repair. Studies showed that muscle glycogen could be restored within 24 hours when sufficient amount of carbohydrate are ingested (Beelen et al., 2010), while recovery process shows better result when protein is ingested together (Burke et al., 2004), thus helps in alleviating muscle soreness (McBrier et al. 2010).

Currently, the recovery beverages industry shows consistent encouraging growth due to the constant high demands in the market, particularly among the athlete population. For instance, sales of Gatorade sports drink in 2015 was amounted to USD1.67 million in the US alone (The Nielsen Co, Dr Pepper Snapple Group Inc. 2016). In Malaysia, some of the popular brands of commercial recovery drinks including Horleys high protein shake, Shaklee ESP Soy Protein, Nestle MILO chocolate malt beverage, and Gatorade sport fuel protein shake. All of these products are milk-based except for Shaklee ESP Soy Protein which is plant-based. Many studies conducted among Caucasian athletes showed that milk-based beverages are effective post-exercise drinks due to rich contents of carbohydrate, protein, vitamins, and electrolytes (Karp et al., 2006; Shireffs et al., 2007; Lee, Maughan \& Shirreffs, 2008; Watson et al., 2008; Cockburn et al., 2010).

Unfortunately, milk-based drinks are not the best choice for active people who suffer from lactose intolerance as ingesting products containing lactose will result in unpleasant symptoms such as bloating, nausea, diarrhea, and vomiting which may interfere with sports performance. A study done by Asmawi and colleagues (2006) have shown that the prevalence of lactose intolerance was high in Asian population with $88 \%$ in Malays, $91 \%$ in Chinese, and $83 \%$ in Indians. Similarly, more than half of the studied population in Thai (Densupsoonton et al., 2004) and Singapore (Bolin et al. 1970) suffer from this digestive problem. Pelly \& Burkart (2013) conducted a survey on dietary regimens among athletes competing in 2010 Commonwealth Games in Delhi reported that $10 \%$ of the athletes from South East Asia countries were likely to follow a low and/or lactose-free diet to avoid the symptoms of lactose intolerance. Based on this statistic, it is imperative for manufacturers and researchers to produce lactose-free recovery beverages.

This study aimed to develop and assess the feasibility of a beverage from sweet corn (Zea mays) as an alternative recovery drink for active people due to its high content of carbohydrate and protein as well as lactose-free. This study also aimed to examine the acceptance of sweet corn juice among exercising people. It was hypothesized that the nutritive values of sweet corn juice are equivalent or at least at par with current recovery drinks and will be accepted as an alternative postexercise beverage among exercising individuals.

\section{MATERIALS AND METHODS}

This study was divided into two phases which were the assessment of nutritional content of sweet corn juice and the sensory evaluation of the product. The participants signed the informed consent upon agreeing to be involved in this study. The procedure was carried out in accordance to the Declaration of Helsinki. All participants were habitual juice consumers, free from food allergies, and were willing to try the sample. This study protocol was reviewed and approved by Universiti Pendidikan Sultan Idris Research Committee. 


\section{Analyses of nutritional content of sweet corn (Zea mays) juice}

Zea mays cooked corn kernel (N28-Nelson's Franchise Sdn. Bhd.) was chosen to be used in this study. This species has its own sweetness taste and it is been planted locally by Nelson's company make it available throughout the year. Referring to the nutrient analysis provided by the manufacturer, the amount of commercially frozen Zea mays kernels was calculated to match the recovery drink formulation as suggested by the previous study (Beelen et al., 2010). Using slow juicer, Zea mays juice was extracted with additional of $3 \mathrm{~g}$ of salt and $300 \mathrm{ml}$ of plain water.

Chemical assays for nutritive values of the sample were carried out in the Analytical and Nutritional Labelling Laboratory of Universiti Kebangsaan Malaysia (UNIPEQ Sdn. Bhd., Selangor). Calorie, carbohydrate, total protein, and fat were identified according to the inhouse method described by Association of the Official Analytical Chemists (AOAC), 16 $6^{\text {th }}$ edition (1995). Types of sugar and amino acid present were identified using high performance liquid chromatography (HPLC) method (Waters 2475, United Kingdom) while Atomic Spectrophotometer (AAS) (GBC Elite 906AA, United Kingdom) was used to calculate the sodium content.

\section{Sensory analysis and consumer acceptance}

Before conducting the sensory evaluation on the sample, a total of thirty male and female volunteers were asked to fill in the modified Product Acceptance questionnaire (Song, 2013) to determine the validity and reliability of the questionnaire. The value of Cronbach's alpha was 0.804, which is high reliability according to Cohen (1988).

Then, another 41 untrained adult panelists were selected for sensory evaluation of the sample. The participants were involved in physical activity more than 3 times per week at least 30 minutes each session and had an experience of recovery drink consumption. After tasting the sample which was served chilled $\left(4^{\circ} \mathrm{C}\right)$, the participants were asked to rate the sample based in its appearance, color, aroma, taste, texture, mouthfeel, and overall like using the 9-point hedonic scale (from $1=$ dislike extremely to $9=$ like extremely). The participants were also required to answer three questions regarding the product acceptance, intent to purchase, and whether they will consume the product after exercise.

Next, the consumer acceptance test was conducted at public places in Tanjung Malim and Kuala Lumpur. A total of 429 participants were voluntarily involved in the taste test and answered the product acceptance questionnaire.

\section{Data analysis}

Data of the study were analyzed using SPSS 23.0. Descriptive statistics such as mean, standard deviation, percentage, and frequency were used to report the feasibility and acceptance of the product. Besides, a two-phase cluster analysis was conducted to identify the amount of groups where the participants have similar response towards the sample. The significant value was set at $\mathrm{p}<0.05$.

\section{RESULTS AND DISCUSSION}

\section{Nutritive values of the sweet corn (Zea mays) juice}

Table 1 shows the nutrient contents of the sweet corn used in this study. The juice contained $57 \mathrm{kcal}$ energy, $68.8 \%$ carbohydrate, $16.8 \%$ protein, $14.2 \%$ fat, and $64.3 \mathrm{mg}$ sodium in $100 \mathrm{ml}$ sample.

Table 1 Nutritive value of sweet corn (Zea mays.) juice.

\begin{tabular}{cc}
\hline Nutrient & Value $(\mathbf{1 0 0} \mathbf{~ m l})$ \\
\hline Calorie $(\mathrm{kcal})$ & 57 \\
Carbohydrate $(\mathrm{g})$ & 9.8 \\
Protein $(\mathrm{g})$ & 2.4 \\
Fat $(\mathrm{g})$ & 0.9 \\
Sodium $(\mathrm{mg})$ & 64.3 \\
\hline
\end{tabular}

The types of sugar and amino acids present in the sample are as shown in Table 2. Fructose and glucose contents were in fair amount with about $0.18 \mathrm{~g}$ and $1.8 \mathrm{~g}$, respectively. Sixteen amino acids present in substantial amounts with the highest contents recorded were alanine $(0.395 \mathrm{~g})$, glutamic acid $(0.394 \mathrm{~g})$, proline $(0.232 \mathrm{~g})$, and leucine $(0.198$ g).

Table 2 Types of sugar and amino acid in $100 \mathrm{ml}$ sample.

\begin{tabular}{cc}
\hline Nutrients & Amount $(\mathbf{g} / \mathbf{1 0 0} \mathbf{m l})$ \\
\hline Types of sugar & 0.18 \\
Fructose & 1.8 \\
Glucose & $<0.01$ \\
Sucrose & $<0.01$ \\
Maltose & \\
Types of amino acids & 0.129 \\
Aspartic Acid & 0.134 \\
Serine & 0.394 \\
Glutamic acid & 0.087 \\
Glycine & 0.040 \\
Histidine & 0.103 \\
Arginine & 0.072 \\
Threonine & 0.395 \\
Alanine & 0.232 \\
Proline & 0.082 \\
Thyrosine & 0.137 \\
Valine & 0.013 \\
Lysine & 0.052 \\
Isoleusine & 0.198 \\
Leucine & 0.088 \\
Phenylalanine & 0.188 \\
Cysteine & \\
&
\end{tabular}

\section{Sensory evaluation and consumer acceptance}

Table 3 shows the responses for seven attributes rated by 41 untrained panelists. Most of the panelists liked the color and aroma of the sample followed by other remaining attributes.

Table 3 Frequency and percentage of panelists response for Likert Scale 6-9 (Like slightly to Like extremely) for sensory attributes of the sample.

\begin{tabular}{cc}
\hline Attributes & Response \\
\hline Appearance & $31(75.6 \%)$ \\
Color & $37(90.3 \%)$ \\
Aroma & $33(80.5 \%)$ \\
Taste & $26(63.5 \%)$ \\
Texture & $32(78.0 \%)$ \\
Mouthfeel & $31(75.6 \%)$ \\
Overall like & $32(78.0 \%)$ \\
\hline
\end{tabular}

Figure 1 shows the diagram of spider web for sensory evaluation of the sample. It demonstrates the intensity for each attribute which was well accepted by all panelists.

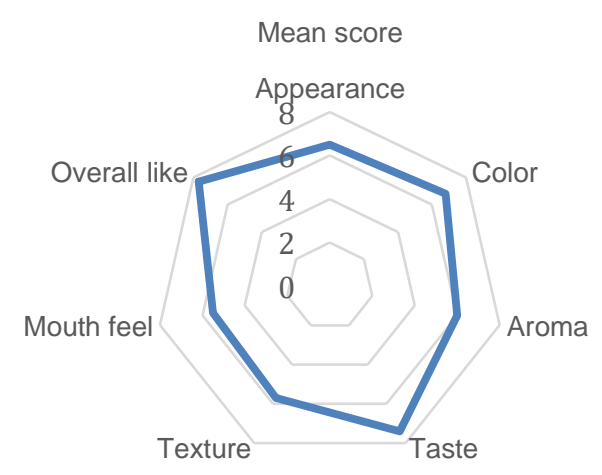

Figure 1 Typical spider plot for intensity of attributes in the sweet corn juice among the untrained panelists.

To determine the consumer acceptance towards the product, a twophase cluster analysis was conducted among 429 consumers. There 
were two clusters formed for the seven attributes being studied. The size of the largest cluster consists of 244 (56.9\%) consumers and the smallest size was $185(43.1 \%)$ consumers with the ratio of 1.32 .

Table 4 demonstrates that the mean score for each attribute was significantly higher $(\mathrm{P}<0.05)$ in cluster 2 (largest cluster) compared to cluster 1 (smallest cluster), indicating that consumers in cluster 2 wellliked the product, while consumers in cluster 1 disliked the juice. Based on the survey conducted, $75.5 \%$ of the consumers said that the product is acceptable, $53.4 \%$ of them were willing to buy the product if it is commercially available, and $54.8 \%$ of them would consume the product after exercise.

Table 4 Comparison of mean score for 7 attributes between clusters.

\begin{tabular}{ccc}
\hline & Cluster & \\
\hline Attributes & $\mathbf{1}(\mathbf{n = 1 8 5})$ & $\mathbf{2}(\mathbf{n = 2 4 4 )}$ \\
\hline Appearance & 4.92 & 7.14 \\
Colour & 6.24 & 7.48 \\
Aroma & 4.65 & 6.82 \\
Taste & 3.48 & 6.70 \\
Texture & 4.50 & 6.94 \\
Mouthfeel & 3.68 & 6.74 \\
Overall like & 4.17 & 7.06 \\
\hline
\end{tabular}

The chemical assays showed that the sweet corn juice in the present study contained high carbohydrate and protein and a fair amount of sodium which were comparable to the nutrient contents of commercially available recovery beverages (Desbrow et al., 2014). In addition, results from sensory evaluation and consumer acceptance study demonstrated that the attributes in the sweet corn juice was accepted by the consumers.

Our product contained approximately $68.8 \%$ carbohydrate, $16.8 \%$ protein, in $100 \mathrm{ml}$ sample. The values were quite similar to the sample used in Trikoomdun and Leenanon (2016) study which comprised of $60.06 \%$ carbohydrate and $13.31 \%$ protein. The sugar contents (combination of fructose, glucose, and others) of the sweet corn juice was comparable to several corn products. For example, sweet corn with kernel cut off cob contains $2.5 \mathrm{~g}$ sugars per $100 \mathrm{~g}$ corn. In another boiled sweet corn with kernel on cob contains $3.78 \mathrm{~g} / 100 \mathrm{~g}$ sample (USDA Nutrient Database, 2011). Meanwhile in our product, the total sugar is $1.06 \mathrm{~g}$ per $100 \mathrm{~m}$ sample. The difference in carbohydrate, protein, and total sugars may be due to different preparation methods or different variety of the corn itself. Regardless, the sweet corn contains high sugar content that contributes to the sweetness of the product. Besides, sweet corn is categorized as moderate to low glycemic index (GI) food, with GI values ranged from 37 to 62 (Atkinson et al., 2008). It has been suggested that this GI food group could fasten the recovery process (Burke et al., 2011). Therefore, sweet corn juice is suitable to be used as recovery beverages for quick muscle glycogen replenishment.

Carbohydrate and protein are essential for the post-exercise recovery. According to Beelen et al. (2010), carbohydrate intake of $1.2 \mathrm{~g} / \mathrm{kg}$ body weight could restore the loss glycogen to an optimal level. Assuming that an athlete body weight is $50 \mathrm{~kg}$, he will need $60 \mathrm{~g}$ of carbohydrate to achieve an optimal recovery effect (Beelen et al., 2010). In our study, sweet corn juice contained $9.8 \mathrm{~g}$ carbohydrate per $100 \mathrm{ml}$ juice. Therefore, theoretically, the athlete needs to consume approximately $612 \mathrm{ml}$ of this juice to restore the glycogen.

It has been suggested that different types of carbohydrate promote glycogen replenishment due to multiple carbohydrate oxidation pathways. Glucose and fructose utilize a different transport pathway to enter body cell and replenish glycogen storage after exercise. Our product contains a fair amount of glucose $(1.8 \mathrm{~g} / 100 \mathrm{ml})$ and fructose $(0.18 \mathrm{mg} / 100 \mathrm{ml})$. Theoretically, by combining these two types of sugar, this will improve carbohydrate absorption and increase the energy supply (Gonzalez et al., 2017). However, this assumption is yet to be established and further research is warranted to examine whether sweet corn juice could enhance sport performance.

Beelen and colleagues (2010) also have proven that consuming both carbohydrate and protein could result in synergistic effect on muscle recovery. Amino acid has been shown to enhance muscle protein synthesis and restore net protein balance which contributes to muscle recovery after exercise (Phillips \& Van Loon, 2001; Reidi et al.,
2014). Branched-chain amino acid (BCAA) can be oxidized in skeletal muscle when sufficient protein is available. It has been discovered that BCAA such as leucine, isoleucine, and valine have beneficial effects in reducing exercise-induced muscle damage effects and promoting muscle-protein synthesis (Negro et al., 2008).

The present study indicated that the sweet corn juice contained $16.8 \%$ protein which comprised of 16 amino acids in total. Alanine made up the highest proportion with $0.395 \mathrm{~g}$ per $100 \mathrm{ml}$ sample, followed by several BCAA which were leucine $(0.198 \mathrm{~g} / 100 \mathrm{ml})$, isoleucine $(0.052 \mathrm{~g} / 100 \mathrm{ml})$, and valine $(0.137 \mathrm{~g} / 100 \mathrm{ml})$. In most of commercially available BCAA supplements, at least $5 \mathrm{~g}$ of BCAA is needed to produce the beneficial effects of BCAA supplementation. Meanwhile, the suggested ratio for leucine:isoleucine:valine is 2:1:1 or 3:1:1 (Kephart et al., 2016). Similar ratio of the BCAA amino acids was obtained in this study which was 2:1:1. Therefore, this finding showed that our product has the potential to be developed as an alternative source of BCAA for muscle recovery purpose.

Sensory evaluation and consumer acceptance findings showed that the sweet corn juice ranked between 6.70 and 7.48 in a 9-point hedonic scale, indicating that the product is well-liked and satisfactorily accepted by majority of the consumers. Looking at the individual attributes, color of the sample was ranked the highest by the consumers, followed by appearance, aroma, overall liking, texture, mouthfeel, and taste. It is not surprising that color and appearance top the lists because they are the most noticeable attributes that create human expectation towards the taste of a product (Vilela \& Cosme, 2016). In producing the sweet corn juice, no artificial was added into the formulation. Hence, the color that attract the consumers was attributed by the natural color of the corn. On the basis of this result, the manufacturers should focus on the color of a product as a marketing strategy to gain the consumers' attention.

Despite the high preference for the appearance of the product, the consumers ranked the taste of the corn juice as the lowest attribute. The bitter and unpleasant flavor perceived by the consumer could be contributed by the addition of sodium into the beverage (Leiper, 2015). Although sodium or table salt is proven to enhance the taste or flavour of food (Institute of Medicine, 2010), adding too much sodium could suppress the sweet taste of the corn kernels. In the current work, sodium was added in the formulation as in most recovery beverages, sodium plays important roles in promoting water retention and accelerating the rehydration process (Stachenfeld, 2008). Thus, more work needs to be done to reformulate the sweet corn juice that is not only effective in rehydrating during strenuous activity, but also has pleasant taste that are favored by the consumers.

Consumers were inquired about the acceptance of the product, intention to purchase, and whether they will consume the product after performing strenuous physical activity. The findings indicated that more than half of the consumers were interested in purchasing and consuming the product if it is commercially available in the market.

\section{CONCLUSION}

The sweet corn juice developed in this study provides high contents of carbohydrate and protein which are vital in enhancing rehydration and muscle recovery during and after training. Additionally, this product has received good acceptance from the participants. Future works are required to elucidate whether sweet corn juice is as effective as commercially available recovery beverages in terms of its capabilities to replenish energy and reduce muscle damage.

\section{ACKNOWLEDGEMENT}

We would like to thank our sponsor, Universiti Pendidikan Sultan Idris for the financial assistance that makes this study possible (grant no: 2017-0022-102-01). Cooperation given by the participants throughout this study was greatly appreciated. 


\section{REFERENCES}

Asmawi, M. Z., Seppo, L., Vapaatalo, H., Korpela, R. 2006. Hypolactasia \& lactase intolerance among three ethnic groups in Malaysia. Indian J. Med. Res. 124(6), 697-704.

Atkinson, F. S., Foster-Powell, K., Brand-Miller, J. C. 2008. International tables of glycemic index glycemic load values: 2008. Diabetes Care. 31(12), 2281-2283.

Beelen, M., Burke, L. M., Gibala, M. J., Van Loon, J. C. 2010. Nutritional strategies to promote post-exercise recovery. Int. J. Sport Nutri and Exer. Metab. 20, 515-532.

Bolin, T. D., Davis, A. E., Seah, C. S., Chua, K. L., Yong, V., Kho, K. M., Siak, C. L., Jacob, E. 1970. Lactose intolerance in Singapore. Gastroenterol. 59 76-84.

Burke, L. M., Kiens, B., Ivy, J. L. 2004. Carbohydrates and fat for training and recovery. J. Sports Sci. 22(1), 15-30.

Burke, L. M., Hawley, J. A., Wong, S. H., Jeukendrup, A. E. 2011. Carbohydrates for training and competition. J. Sports Sci. 29(S1), S17-S27.

Cockburn, E., Stevenson, E., Hayes, P. R., Robson-Ansley, P., Howatson, G. 2010. Effect of milk-based carbohydrate-protein supplement timing on the attenuation of exercise induced muscle damage. Appl. Physiol. Nutr. Metab. J. 35, 270-277.

Cohen J. 1988. Statistical Power Analysis for the Behavioral Sciences $\left(2^{\text {nd }}\right.$ Edition). New York: Lawrence Erlbaum Associates.

Densupsoontom, N., Jiranpiyo, P., Thamonsiri, N., Wongam, R. 2004. Lactose intolerance in Thai adults. J. Med. Assoc. Thai. 87(12), 1501-1505.

Desbrow, B., Jansen, S., Barrett, A., Leveritt, M. D., Irwin, C. 2014. Comparing the rehydration potential of different milk-based drinks to a carbohydrate-electrolyte beverage. Appl. Physiol. Nutr. Metab. J. 39(12), 1366-1372.

Gonzalez, J. T., Fuchs, C. J., Betts, J. A., van Loon, L. J. C. 2017. Glucose plus fructose ingestion for post-exercise recovery-greater than the sum of its parts? Nutr. 9(344).

Institute of Medicine (US) Committee on Strategies to Reduce Sodium Intake (2010). Henney JE, Taylor CL, Boon CS, editors. Strategies to Reduce Sodium Intake in the United States. Washington (DC): National Academies Press (US)

Karp, J. R., Johnston, J. D., Tecklenburg, S., Mickleborough, T. D., Fly, A. D., Stager, J. M. 2006. Chocolate milk as a post-exercise recovery aid. Int. J. Sport Nutr. Exerc. Metab. 16, 78-91.
Kephart, W. C., Mumford, P. W., McCloskey, A. E., Holland, A. M., Shake, J. J., et al. 2016. Post-exercise branched chain amino acid supplementation does not affect recovery markers following three consecutive high intensity resistance training bouts compared to carbohydrate supplementation. J. Int. Soc. Sports Nutr. 13(30), 1-10.

Lee, J. K., Maughan, R. J., Shirreffs, S. M. 2008. Effects of milk ingestion on prolonged exercise capacity in young healthy men. Nutr. 24, 340-347.

Leiper, J. B. 2015. Fate of ingested fluid: Factors affecting gastric emptying and intestinal absorption of beverages in humans. Nutr. Rev. 73 (S2), 57-72.

McBrier, N. M., Vairo, G. L., Bagshaw, D., Lekan, J. M., Bordi, P. L., KrisEtherton, P. M. 2010. Cocoa-based protein and carbohydrate drink decreases perceived soreness after exhaustive aerobic exercise: A pragmatic preliminary analysis. J. Strength Cond. 24(8), 2203-2210.

Negro, M., Giardina, S., Marzani, B., Marzatico, F. 2008. Branch-chain amino acid supplementation does not enhance athletic performance but affects muscle recovery and the immune system. J. Sports Med. Phys. Fitness. 48 (3), 347-351.

Pelly, F. E., Burkart, S. J. 2014. Dietary regimes of athletes competing at the Delhi 2010 Commonwealth Games. Int. J. Sport Nutr. Exerc. Metab. 24(1), 28-36.

Phillips, S. M., Van Loon, L. J. 2011. Dietary protein for athletes: from requirement to optimum adaptation. J. Sports Sci. 29 Suppl 1, S29-S38.

Reidy, P. T., Konopka, A. R., Hinkley, J. M., Suer, M. K., Harber, M.P. 2014. The effect of feeding during recovery from aerobic exercise on skeletal muscle intracellular signalling. Int. J. Sport Nutr. Exerc. Metab. 24, 70 -78.

Shireffs, S. M., Watson, P., Maughan, R. J. 2007. Milk as an effective postexercise rehydration drink. Br. J. Nutr. 98, 173-180.

Song L. 2013. Yogurt cultured milk powder as a substitute for yogurt powder (Unpublished master dissertation). Louisiana State University, USA.

Stachenfeld, N. S. 2008. Acute effects of sodium ingestion on thirst and cardiovascular function. Curr. Sports Med. Rep. 7(4), S7-S13.

The Nielsen Co, Dr Pepper Snapple Group Inc. (2016). 2016 DPS annual report. Texas, USA.

Trikoomdun, W., Leenanon, B. 2016. Production of corn milk yogurt supplemented with probiotics. Int. Food Res. J. 23(4), 1733-1738.

USDA Nutrient Database (2011). USDA Food Composition database. Retrieved on April 12, 2018 from Website: https://ndb.nal.usda.gov/ndb/

Vilela, A., Cosme, F. 2016. Drink red: Phenolic composition of red fruit juices and their sensorial acceptance. Beverages. 2(29), 1-13.

Watson, P., Love, T. D., Maughan, R. J., Shirreffs, S. M. 2008. A comparison of the effects of milk and a carbohydrate-electrolyte drink on the restoration of fluid balance and exercise capacity in a hot, humid environment. Eur. J. Appl. Physiol. 104, 633-642. 